\title{
PENERAPAN MODEL WATERFALL PADA SISTEM INFORMASI BEASISWA BERBASIS WEB
}

\author{
Agustina Mardeka Raya ${ }^{1)}$, Hamidah $^{2)}$, Kiswanto ${ }^{3)}$, Elly Yaniarti ${ }^{4)}$ \\ ${ }^{1,2,3,4)}$ Sistem Informasi, Institut Sains dan Bisnis Atma Luhur, Pangkalpinang, Bangka \\ Belitung \\ email: agustinamardekaraya@atmaluhur.ac.id ${ }^{1)}$, hamidah@atmaluhur.ac.id ${ }^{2}$, \\ Kiswanto@atmaluhur.ac.id ${ }^{3)}$, Elly@atmaluhur.ac.id ${ }^{4}$
}

\begin{abstract}
Abstrak
Kemajuan teknologi informasi yang berkembang di dunia pendidikan, membuat kampus Atma Luhur selalu ingin mengembangkan teknologi informasi termasuk dalam pemberian beasiswa. Informasi beasiswa pada kampus Atma Luhur belum banyak diketahui para mahasiswa dan calon mahasiswa baru. Saat ini tidak ada sistem untuk membantu proses pendaftaran serta pengelolaan beasiswa pada kampus Atma Luhur. Oleh sebab itu dibutuhkan suatu sistem informasi beasiswa berbasis web agar mempermudah mahasiswa untuk mendapatkan informasi serta melakukan pendaftaran beasiswa sehingga setiap mahasiswa berhak untuk mendaftar dan mendapatkan beasiswa untuk membantu bagian kemahasiswaan dalam mengelola data. Sistem Beasiswa ini akan dibuat berdasarkan model pengembangan perangkat lunak Waterfall. Pemodelan perangkat lunak digambarkan dengan UML (Unified Manipulation Language). Penelitian ini menghasilkan Sistem Informasi Beasiswa berbasis web menggunakan Model waterfall dengan Metode berorientasi objek. Pengujian perangkat lunak menggunakan metode User Acceptance Test mendapatkan hasil sebesar 84\%.
\end{abstract}

Kata Kunci : Sistem Informasi, Sistem, Beasiswa, Waterfall, Web.

\begin{abstract}
The advancement of information technology that is developing in the world of education has made the Atma Luhur campus always want to develop information technology, including in providing scholarships. Scholarship information on the Atma Luhur campus is not widely known by students and prospective new students. Currently, there is no system to assist the registration process and scholarship management at the Atma Luhur campus. Therefore we need a web-based scholarship information system to make students easier to get the information and register for scholarships so that every student has the right to register and get scholarships to help the student affairs department in managing data. This Scholarship System will be based on the Waterfall software development model. Software modeling is described by UML (Unified Manipulation Language). This research produces a web-based scholarship information system that using waterfall model with object-oriented methods. Software testing using the User Acceptance Test method yields $84 \%$ results.
\end{abstract}

Keywords: Information system, Scholarship, Waterfall, Web.

\section{PENDAHULUAN}

Teknologi informasi berkembang begitu pesat. Teknologi Informasi ini telah berpengaruh ke semua aspek pada

JURSIMA

Jurnal Sistem Informasi dan Manajemen kehidupan masyarakat. Tak terkecuali di bidang pendidikan. Teknologi informasi dapat membuat pekerjaan lebih efektif dan efisien [1]. Beasiswa adalah bantuan 
keuangan atau tunjangan yang dibiayai atau difasilitasi oleh yayasan, pemerintah atau lembaga pendidikan maupun perusahaan kepada pelajar untuk mendapatkan bantuan biaya pendidikan [2]. Beasiswa juga dapat diartikan sebagai bentuk penghargaan terhadap prestasi yang dihasilkan oleh mahasiswa/pelajar [3]. Bentuk beasiswa bisa berupa beasiswa yang ditanggung penuh biaya pendidikannya, ada yang ditanggung hanya separuh biaya pendidikannya, ada juga yang ditanggung seluruh biaya pendidikan serta biaya hidup atau beasiswa yang hanya ditanggung tiket pesawat pulang atau pergi selama pendidikan berlangsung.

Setiap beasiswa memiliki kriteria yang berbeda-beda. Untuk beasiswa (Bantuan Biaya Pendidikan) mahasiswa tidak mampu secara ekonomi dari pemerintah provinsi kepulauan Bangka Belitung diberikan pada saat Mahasiswa baru mendaftar perkuliahan. Sedangkan untuk Beasiswa Peningkatan Prestasi Akademik (PPA) dan Bantuan Biaya Pendidikan Peningkatan Prestasi Akademik (BPP-PPA) dari Kopertis Wilayah 2 diberikan kepada Mahasiswa pada dua Semester tertentu.

Calon mahasiswa yang ingin mendafatar beasiswa Provinsi, harus melakukan pendaftaran di kampus. Dengan situasi seperti ini calon mahasiswa yang ingin mendaftar beasiswa menjadi malas untuk mendaftar karena keterbatasan waktu yang dimiliki. Sedangkan Beasiswa Peningkatan Akademik (PPA) dan Bantuan Biaya Pendidikan Peningkatan Prestasi Akademik (BPP-PPA) tidak ada proses pendaftaran. Tetapi mahasiswa yang mendapatkan Beasiswa PPA dipilih langsung berdasarkan Indeks Prestasi Kumulatif (IPK) tertinggi dari semua mahasiswa per jurusannya dan berdasarkan kriteria yang ada. Situasi seperti ini dapat mengakibatkan setiap mahasiswa menerima lebih dari satu jenis beasiswa, serta jumlah mahasiswa yang ingin mengajukan diri sebagai penerima beasiswa cukup banyak, tetapi informasi penerimaan beasiswa tidak sampai ke semua mahasiswa. Terlebih lagi pemilihan beasiswa ini masih terbatas pada ruang lingkup tertentu dan masih bersifat konvensional dan subjektif.

\section{METODE PENELITIAN}

\section{A. Metode Pengembangan Perangkat Lunak}

Metode pengembangan perangkat lunak yang digunakan pada penelitian sistem informasi beasiswa ini menggunakan model Waterfall. Model Waterfall merupakan metode pengembangan perangkat lunak yang mengusulkan pendekatan kepada perangkat lunak yang sekuensial dan sistematik, mulai pada tingkat kemajuan sistem pada seluruh analisis, desain, kode, pengujian dan pemeliharaan [4]. Pengembangan sistem menggunakan model waterfall ini lebih terstruktur [5].

Model waterfall juga biasa disebut SDLC (System Development Life Cycle) [6]. Pendekatan model waterfall merupakan model SDLC yang digunakan pertama dan digunakan secara luas dalam Rekayasa Perangkat Lunak untuk melihat keberhasilan proyek [7]. Informasi Beasiswa. https://ejournal.stmikgici.ac.id/ STMIK GICI 


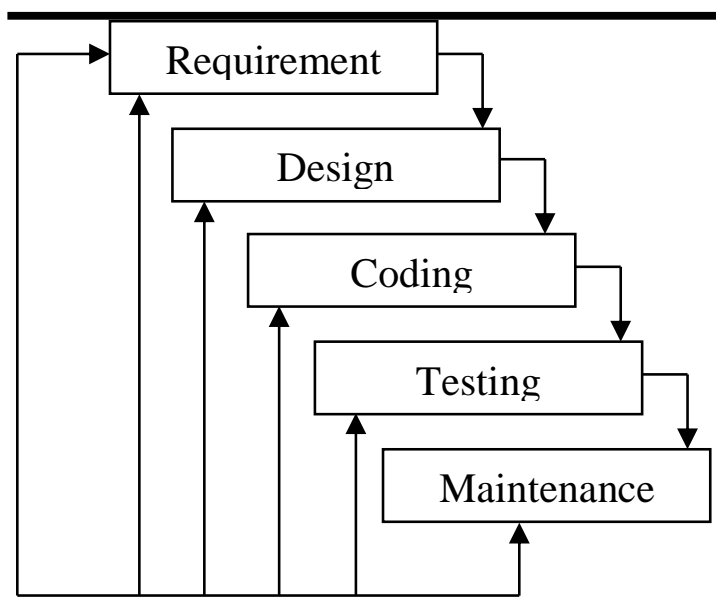

Gambar 1. Model Waterfall (Jogianto, 2012)

\section{B. Metode Permodelan Perangkat Lunak}

Metode pemodelan perangkat lunak yang digunakan pada penelitian ini adalah UML (Unified Modeling Language) yang merupakan salah satu standar bahasa yang digunakan pada dunia industri yang mana bertujuan untuk mendefinisikan requirement, membuat analisis dan desain, serta menggambarkan arsitektur dalam pemrograman berorientasi objek [8]. Penggunaan UML tidak dibatasi oleh metodologi tertentu, walaupun kenyataannya UML adalah pemodelan perangkat lunak yang paling banyak digunakan pada metodologi berorientasi objek.

\section{Metode Pengujian Perangkat Lunak}

Pada Penelitian ini pengujian perangkat lunak pada penelitian ini menggunakan metode (User Acceptance Test) UAT. UAT merupakan proses verifikasi sistem yang diuji oleh pengguna [9]. Tujuan dari UAT adalah mengumpulkan masukan dari pengguna sistem yang sebenarnya, mereka yang

\section{JURSIMA}

Jurnal Sistem Informasi dan Manajemen memiliki pengalaman dengan proses bisnis sistem dan sistem tersebut akan mereka gunakan [10].

\section{HASIL DAN PEMBAHASAN}

\section{A. Requirment}

Requirment merupakan tahapan awal yang bertujuan untuk menganalisa kebutuhan sistem. Tahapan requirment pada penelitian ini adalah observasi dan wawancara. Hasil analisa requirment digambarkan dalam bentuk Activity Diagram. Di bawah ini adalah gambaran activity diagram yang didapat dari analisa requirment.

\section{a. Activity Diagram Beasiswa} Provinsi:

Activity ini menggambarkan proses bisnis untuk mendaftar beasiswa provinsi di STMIK Atma Luhur.

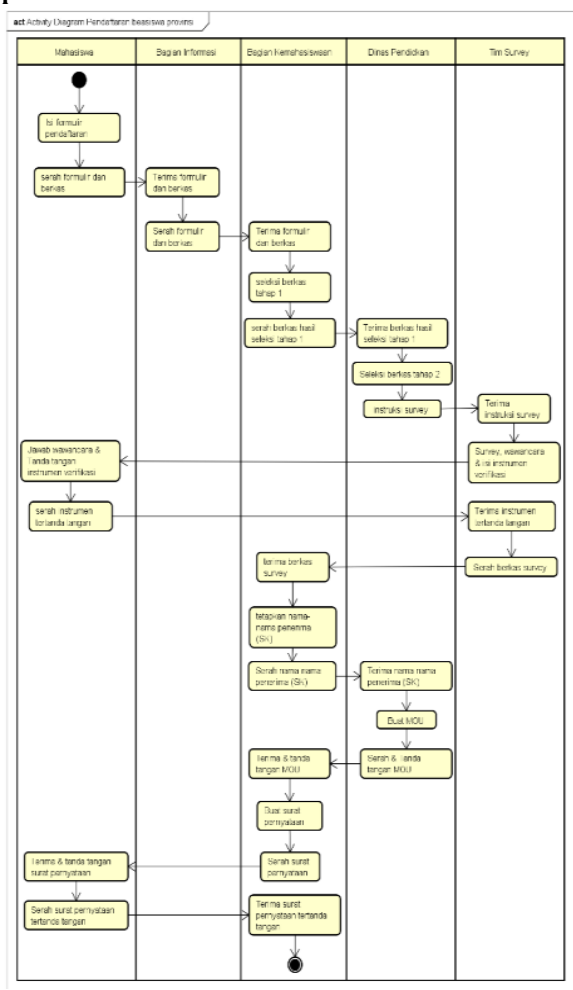

Gambar 2. Activity Diagram Beasiswa Provinsi

https://ejournal.stmikgici.ac.id/ STMIK GICI 
b. Activity Diagram Pembuatan Laporan Beasiswa Provinsi. act Activity Proses Pembuatan Laporan Beasiswa Provinsi J

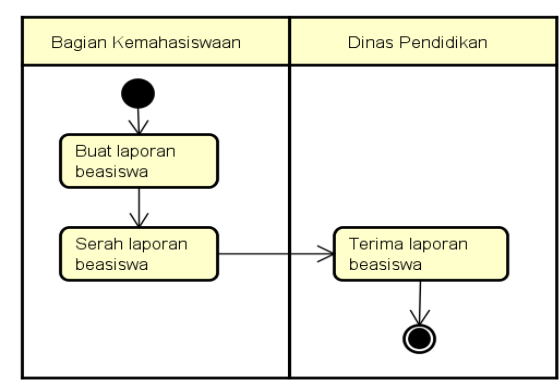

Gambar 3. Activity Diagram

Pembuatan Laporan Beasiswa Provinsi

c. Activity Diagram Beasiswa Kopertis:

Activity di bawah ini menggambarkan aktifitas yang dilakukan pada proses pendaftaran beasiswa kopertis.

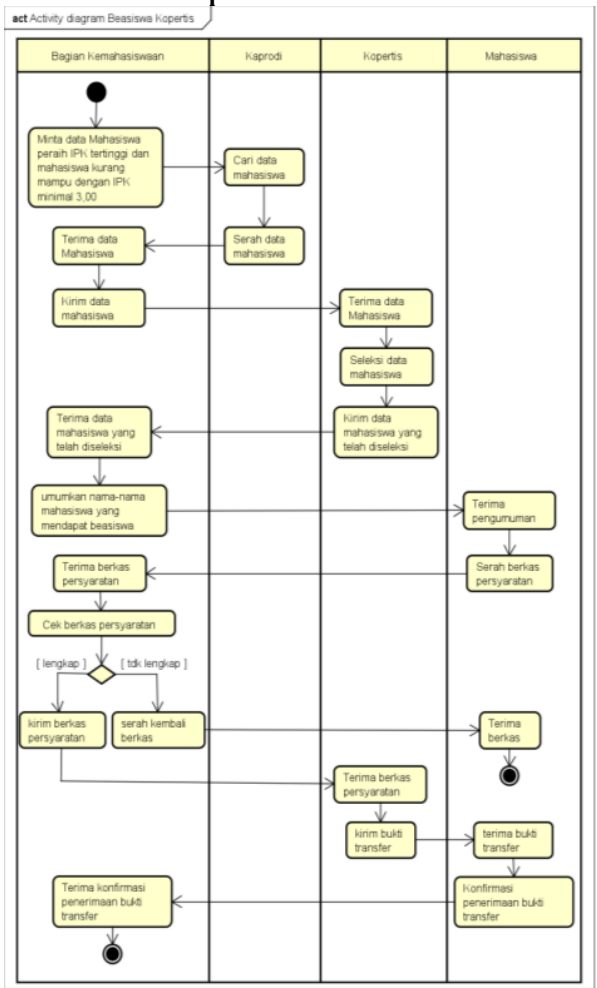

Gambar 4. Activity Diagram

Beasiswa Kopertis

JURSIMA

Jurnal Sistem Informasi dan Manajemen
B. Design

Design merupakan proses menerjemahkan kebutuhan sistem kedalam sebuah model perangkat lunak yang berdasarkan requierment. Untuk pemodelan sistem digambarkan dalam dengan Use Case Diagram. Rancangan basis data digambarkan dengan Class Diagram.

a. Use Case Diagram Admin

Use Case ini menggambarkan menu-menu dan aktivitas yang akan dilakukan oleh admin pada halaman admin.

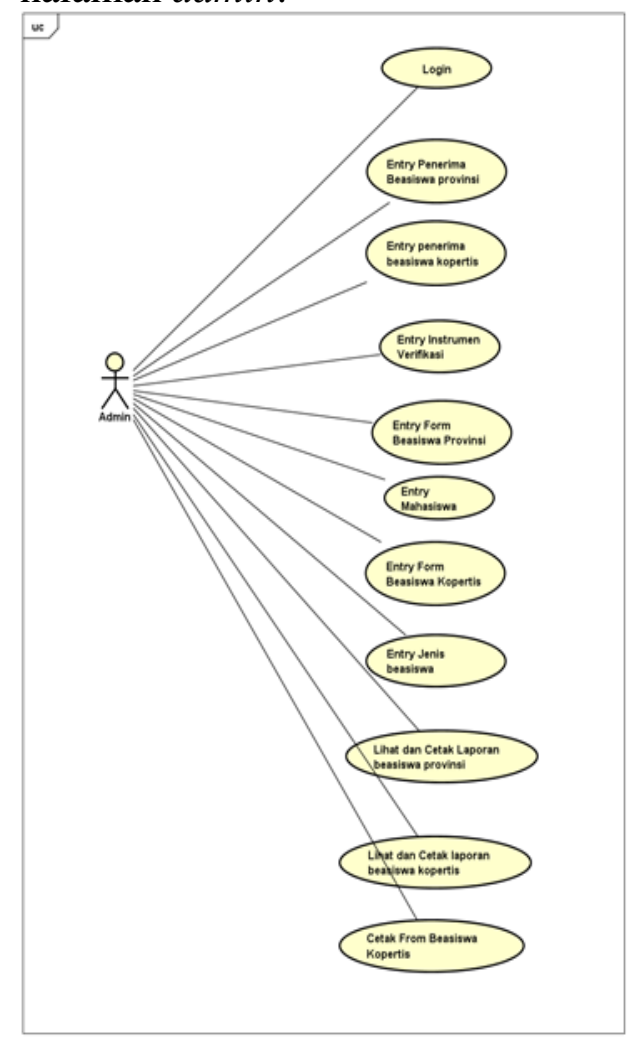

Gambar 5. Use Case Diagram Admin

b. Use Case Diagram Mahasiswa Use Case ini menggambarkan menu-menu dan aktivitas yang akan dilakukan oleh mahasiswa pada halaman mahasiswa.

https://ejournal.stmikgici.ac.id/ STMIK GICI 


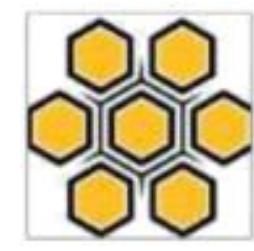

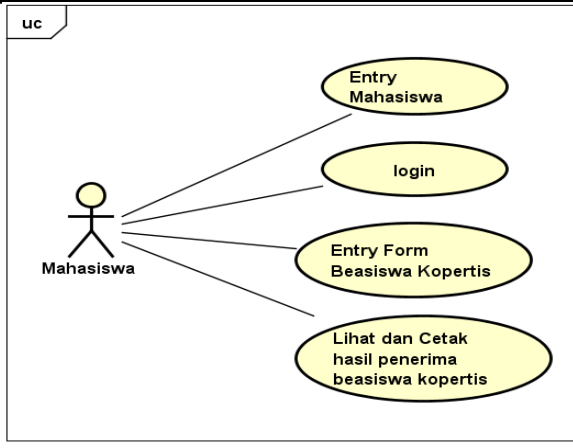

Gambar 6. Use Case Diagram Mahasiswa

c. Use Case Diagram Camaba Use Case ini menggambarkan menu-menu dan aktivitas yang akan dilakukan oleh camaba pada halaman camaba.

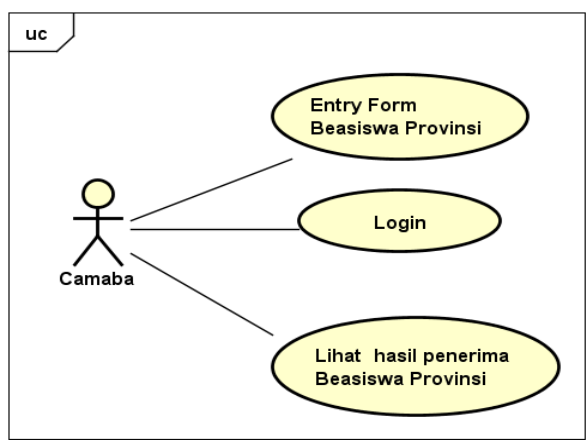

Gambar 7. Use Case Diagram Camaba

d. Use Case Diagram Puket III

Use Case ini menggambarkan menu-menu dan aktivitas yang akan dilakukan oleh Puket III pada halaman Puket III.

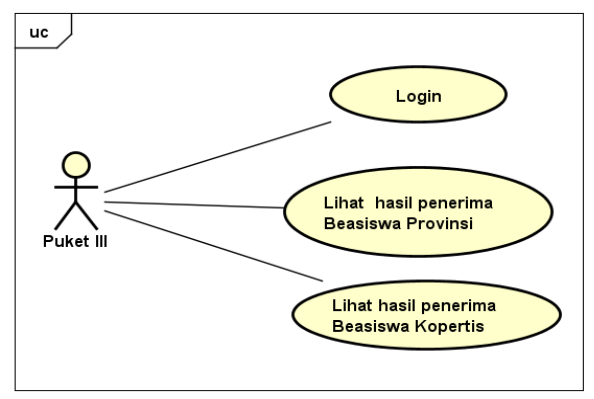

Gambar 8. Use Case Diagram Mahasiswa

JURSIMA

Jurnal Sistem Informasi dan Manajemen e. Class Diagram

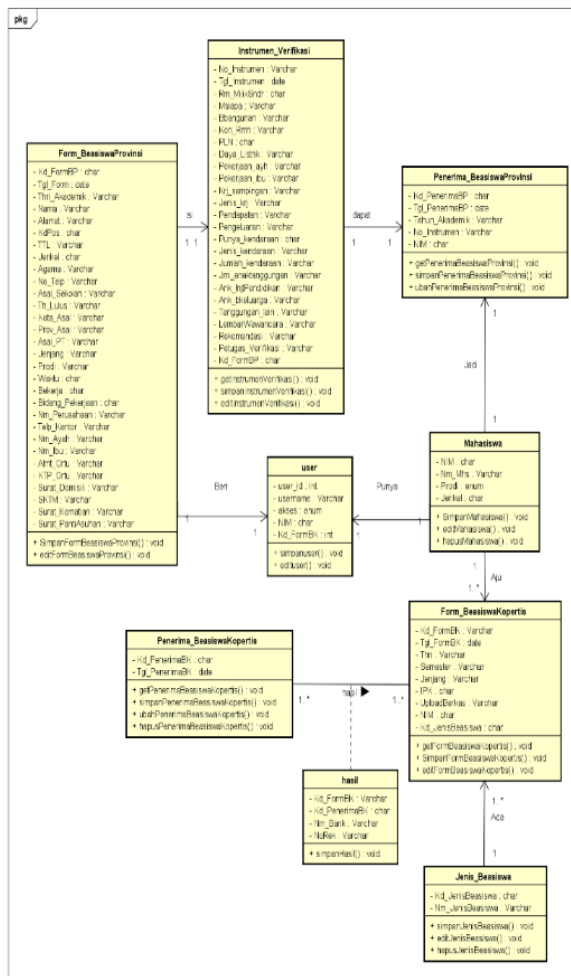

Gambar 9. Class Diagram

\section{Testing}

Pengujian dilakukan dengan menggunakan kuesioner yang diisi oleh user yang telah menggunakan sistem ini untuk diuji. Pengujian dilakukan dengan model User Acceptance Test. Kuesioner pengujian ini dihitung berdasarkan skala linkert. Pembobotan skala linkert adalah sebagai berikut:

\begin{tabular}{|c|c|c|}
\hline \multicolumn{3}{|r|}{ bel 1. Bobot Skala Linkert } \\
\hline Bobot & & Keterangan \\
\hline 5 & SB & $\begin{array}{l}\text { Sangat Baik (Sangat : } \\
\text { Mudah/Bagus/Sesuai/Jelas) }\end{array}$ \\
\hline 4 & BK & Baik (Mudah/Bagus/Sesuai/Jelas) \\
\hline 3 & BS & Biasa Saja (Netral) \\
\hline 2 & BR & $\begin{array}{l}\text { Buruk (Cukup : } \\
\text { Sulit/Bagus/Sesuai/Jelas) }\end{array}$ \\
\hline 1 & BS & $\begin{array}{l}\text { Buruk Sekali (Sangat: } \\
\text { Sulit/Jelek/Tidak Sesuai/Tidak } \\
\text { Jelas) }\end{array}$ \\
\hline
\end{tabular}

https://ejournal.stmikgici.ac.id/ STMIK GICI 
Kuesioner ini diisi oleh 25 responden, untuk selanjutnya di analisa dari setiap jumlah untuk mendapatkan rata-rata nilai.

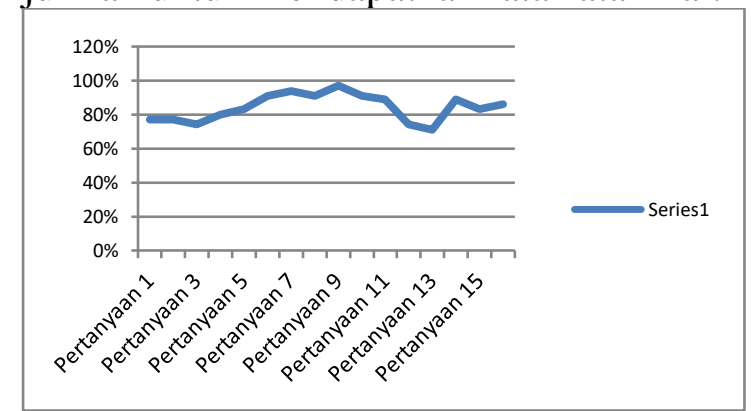

Gambar 10. Grafik Presentase Tiap Pertanyaan Kuesioner UAT

Gambar 10 adalah grafik presentase tiap pertanyaan yang telah diisi oleh responden pada kuesioner User Acceptance Test. Nilai tertinggi ada pada pertanyaan nomor 9. Dari hasil perhitungan yang telah dilakukan berdasarkan skala linkert adalah sebesar $84 \%$.

\section{Maintenance}

a. Halaman Utama

Halaman utama ini adalah halaman yang tampil saat masuk ke alamat web sistem beasiswa. Pada halaman utama ini terdapat menu login yang digunakan untuk login sebagai admin atau sebagai user. Serta terdapat menu form beasiswa provinsi dan menu form beasiswa kopertis, seperti yang ada pada Gambar 11.

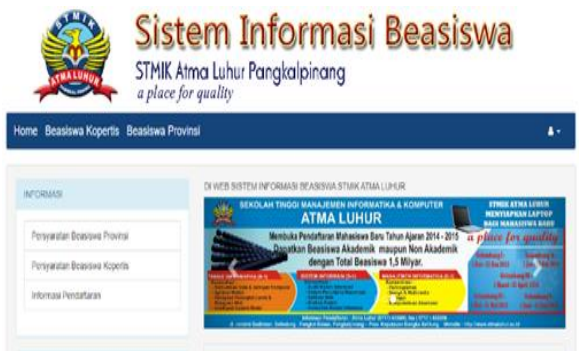

Gambar 11. Halaman Utama

JURSIMA

Jurnal Sistem Informasi dan Manajemen b. Halaman Administrator

Halaman administrator merupakan halaman khusus admin web sistem beasiswa yang didalamnya terdapat menu menu yang tidak ada di menu halaman user. Menu-menu tersebut dapat dilihat pada Gambar 12.

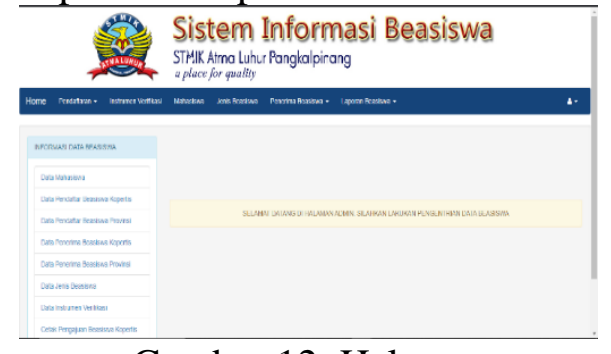

Gambar 12. Halaman

Administrator

c. Halaman Mahasiswa

Halaman mahasiswa merupakan halaman khusus mahasiswa yang di dalamnya terdapat menu untuk para mahasiswa mendaftar beasiswa dan melihat hasil penerima beasiswa. Menu-menu pada halaman mahasiswa dapat dilihat pada gambar dibawah ini.

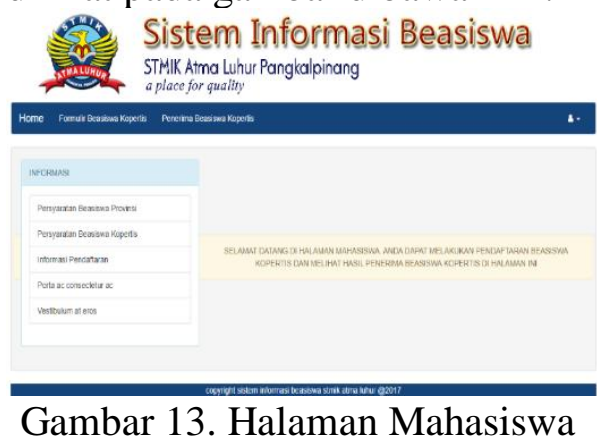

\section{SIMPULAN}

Setelah melakukan analisis terhadap Sistem Informasi Beasiswa pada STMIK Atma Luhur dari pembahasan yang telah jelaskan dapat disimpulkan sebagai berikut : 1. Adanya sistem informasi beasiswa berbasis web ini dapat meningkatkan

https://ejournal.stmikgici.ac.id/ STMIK GICI 
kinerja proses pelayanan bagian kemahasiswaan khususnya pelayanan pendaftaran beasiswa sehingga pelayanan dapat memuaskan bagi mahasiswa STMIK Atma Luhur.

2. Adanya sistem ini, pengelohan data beasiswa dan data pemohon beasiswa akan efisien dan menghasilkan informasi yang lebih tepat, akurat dan cepat.

3. Adanya sistem ini, akan membantu mengatasi masalah pada proses penyampaian informasi beasiswa dan perekrutan calon penerima beasiswa di STMIK Atma Luhur.

Berdasarkan kesimpulan diatas dan sebagai pertimbangan bagi Bagian Kemahasiswaan STMIK Atma Luhur Pangkalpinang guna meningkatkan pelayanan dan kinerja sistem.

\section{DAFTAR PUSTAKA}

[1] D. Rahman and H. Yunitasari, "Perancangan Sistem Inventory Kebutuhan Produksi Pakaian Berbasis Web ( Studi Kasus Pada Pt . Bba Bodynits Batam )," J. Sist. Inf. dan Manaj., vol. 8, no. 2, 2020.

[2] N. Alberta, Kiat-kiat Berburu dan Tembus Beasiswa Pendidikan di Luar Negeri. Depok: Huta Pablisher, 2016.

[3] S. Nurhalimah, T. Tampubolon, W. B. Berutu, J. Simarmata, and Mesran, "Sistem Pendukung Keputusan Penerimaan Beasiswa Pada AMIK STIEKOM Sumatera Utara Menggunakan Metode VIKOR," Semin. Nas. Sains Teknol. Inf., pp. 753-758, 2018.

[4] R. S. Pressman, Rekayasa Perangkat Lunak (Pendekatan Praktisi), 7th ed.
Yogyakarta: Offset, Andi, 2012.

[5] A. Ibrahim, A. Rifai, and L. Oktarina, "Rancang Bangun Aplikasi Pencatatan Data Kependudukan Kelurahan Pahlawan Berbasis Web," J. Sist. Inf., vol. 8, no. 1, pp. 947-957, 2016.

[6] S. K. Sianturi et al., "PERANCANGAN SISTEM LIBRARY BERBASIS WEB," vol. 9, no. 1, 2021.

[7] T. U. G. Jr, "Evaluation of Le MaC Wireless Storage Management System by Modified Waterfall Model," World Sci. News, vol. 144, no. March, pp. 43-55, 2020.

[8] R. A.S and M. Shalahuddin, "Rekayasa Perangkat Lunak Terstruktur dan Berorientasi Objek. Bandung: Informatika," J. Pilar Nusa Mandiri, 2015.

[9] E. V. Sandin, N. M. Yassin, and R. Mohamad, "Comparative Evaluation of Automated Unit Testing Tool for PHP," Int. J. Softw. Eng. Technol., vol. 3, no. 2, pp. 7-11, 2016.

[10] K. S, LIMS user acceptance testing. Quality Assurance. Good, 2003. https://ejournal.stmikgici.ac.id/ STMIK GICI 